\title{
JURNAL ILMIAH MIMBAR DEMOKRASI
}

\section{KEBIJAKAN PEMERINTAH KOTA SURABAYADALAMPENUMBUHAN BUDAYA BACA DI KALANGAN PELAJAR}

\author{
Oleh: Herman Hendrik, Lukman Solihin, Noviyanti, \\ Indah Pratiwi, Kaisar Julizar*
}

\begin{abstract}
This article is aimed at describing the role of Surabaya City Administration in nurturing the culture of reading. Presevious studies show that literacy level in Indonesia is relatively low. Inspite of its achievement in eradicating illiteracy, Indonesia has not managed nurturing the culture of reading. In decentralization era, local governments (provincial and regency/city) have vital roles in policy making. They have wider spaces for innovations and creativities in developing their societies and regions, based on the authorities that the central government transferred to them. This context made it possible for the Surabaya City Administration to make policies supporting the nurturing of the culture of reading. This article is based on a field research using qualitative method conducted in Surabaya City. The data of the research resulted from interviews with relevant parties, they are personnel of the Office of Educational Affairs of Surabaya City and the Board of Archive and Library of Surabaya City, and also desk studies. The findings of the research show that in the middle of limited policy instruments available for nurturing literacy, especially nurturing the culture of reading, Surabaya City Administration declared itself as a "city of literacy", followed by many policies supporting the development of literacy. Those policies are the issuance of literacy-supporting regulations, synergy among related government agencies, human resources development, implementation of literacy events, and education ecosystem envionment. The result of the policies is the increase in the reading interest of the people supported by sustainable literacy programs.
\end{abstract}

Keywords: Lliteracy, library, decentralization, local government.

*Peneliti pada Pusat Penelitian Kebijakan Pendidikan dan Kebudayaan, Badan Penelitian dan Pengembangan Kementerian Pendidikan dan Kebudayaan 
PENDAHULUAN

Desentralisasi memungkinkan pemerintah daerah untuk membuat kebijakan yang dianggap sesuai kebutuhan masyarakat dan wilayahnya, termasuk dalam bidang pendidikan. Pemerintah daerah dapat menentukan program beserta penganggarannya secara mandiri sesuai dengan visi dan misi masing-masing. Secara umum, desentralisasi di Indonesia ditujukan untuk meningkatkan efektivitas dan efisiensi dalam penyediaan pelayanan publik dan program-program pembangunan serta untuk meningkatkan independensi pemerintah daerah beserta masyarakatnya. Secara spesifik, desentralisasi dalam bidang pendidikan ditujukan bagi perbaikan kualitas pendidikan di daerah. Implementasi desentralisasi dalam bidang pendidikan di Indonesia di antaranya ditempuh dengan pemangkasan wewenang dan peran pemerintah pusat, dalam hal ini instansi yang mengampu urusan pendidikan, yang kemudian berujung pada pelimpahan wewenang untuk mengurus sekolah dasar (SD) dan sekolah menengah pertama (SMP, atau sekolah lanjutan tingkat pertama, SLTP) kepada kabupaten kota sementara sekolah menengah atas (SMA, atau sekolah lanjutan tingkat atas, SLTA) kepada pemerintah provinsi.

Implementasi desentralisasi dalam bidang pendidikan juga tampak dalam penghapusan kantor-kantor wilayah departemen yang mengurusi pendidikan. Pelimpahan wewenang itu juga diserta dengan pelimpahan untuk mengelola keuangan yang berkaitan dengan pendidikan (Toi 2010). Dengan wewenangnya yang lebih besar, pemerintah daerah bisa lebih leluasa untuk mengatur segala urusan yang dilimpahkan dari pusat serta menentukan mekanismemekanisme pendanaan yang dijalankan, termasuk dalam urusan pendidikan. Bertambahnya wewenang itu berimplikasi pada banyak hal. Salah satu contoh dampak dari hal tersebut yang dapat diamati adalah banyaknya pemerintah daerah yang berani menyediakan pendidikan dasar secara gratis (Rosser \& Sulistiyanto 2013).

Salah satu hal yang krusial dalam bidang pendidikan adalah pengembangan literasi, atau lebih spesifik penumbuhan budaya baca. Literasi menjadi penting karena merupakan salah satu indikator dalam pembangunan. Dengan kata lain, literasi merupakan wahana untuk mencapai kesejahteraan karena literasi memungkinkan seseorang untuk mendapatkan atau menguasai pengetahuan-pengetahuan dan keterampilan-keterampilan lain (Hastari 2015 dan Wahyudin 2015). Desentralisasi membuka kemungkinan-kemungkinan bagi pembuatan kebijakan yang sesuai 
dengan konteks kedaerahan (Wahyudin 2015). Secara khusus, dalam hal ini desentralisasi memberi kesempatan kepada pemerintah daerah untuk mengeluarkan kebijakan yang dapat menumbuhkan budaya baca sesuai dengan kebutuhan dan konteks masyarakat dan wilayahnya.

Kebijakan yang diarahkan untuk menumbuhkan budaya baca menjadi penting karena, berdasarkan data, Indonesia termasuk lemah dalam hal itu. UNESCO merilis data yang menunjukkan data bahwa minat baca masyarakat Indonesia termasuk rendah. Hasil survei UNESCO tentang minat baca masyarakat Indonesia memperlihatkan angka 0,001, yang berarti bahwa dari 1.000 orang penduduk Indonesia, hanya satu orang yang memiliki minat baca tinggi (Kompas 28/08/2015). Lebih jauh, laporan PIRLS pada tahun 2011 mengenai rata-rata indeks budaya baca menunjukkan bahwa dengan skala 0-1000 Indonesia masih berada pada level negara dengan budaya baca terendah di bawah rata-rata skala PIRLS, yaitu 428. Dari 45 negara yang menjadi sampel, Indonesia berada pada peringkat 42 , hanya di atas Qatar, Oman dan Moroko (Mullis et al. 2011). Khusus untuk konteks pelajar, data dari PISA pada tahun 2012 menunjukkan bahwa skor kemampuan membaca pelajar Indonesia adalah 396, 100 poin di bawah rata-rata negara-negara OECD, yaitu 496, yang menempatkan
Indonesia di posisi 64 dalam urutan negara-negara OECD berdasarkan kemampuan membaca siswanya (OECD 2010).

Hal ini tampak kontradiktif, mengingat Indonesia termasuk sukses dalam mengentaskan masalah buta huruf. Data dari UNESCO menunjukkan bahwa indeks literasi Indonesia sudah mencapai 99.1\% (UNESCO, 2012). Tampaknya

kemampuan baca-tulis tidak berbanding lurus dengan minat baca masyarakat. Kemampuan baca-tulis dengan demikian belum menjadi kebiasaan atau belum menjadi budaya. Kemampuan literasi dasar itu sekadar untuk memenuhi keperluan fungsional, yaitu menyelesaikan tugas dan pekerjaan. Sehubungan dengan itu, dapat dikatakan bahwa kebijakan merupakan determinan penting dalam mengembangkan budaya baca.Dalam rangka mewujudkan budaya membaca, diperlukan lingkungan yang mendukung praktik-praktik budaya literasi (IFLA 2007). Kebijakan yang mendukung kebiasaan membaca merujuk kepada penyediaan koleksi dan fasilitas dan implementasi program-program yang terkait dengan promosi budaya membaca (Laksmi 2007).

$$
\text { Kebijakan dalam rangka }
$$
menumbuhkan budaya baca termasuk ke dalam kebijakan pendidikan, khususnya terkait dengan sekolah dan perpustakaan. 
Sekolah merupakan salah satu institusi yang bertanggung jawab dalam mewujudkan budaya baca. Hal tersebut karena sekolah merupakan lembaga pendidikan formal dimana siswa seharusnya diakrabkan kegiatan membaca, yang merupakan bagian penting dalam kegiatan belajar. Lebih jauh, dalam lampiran Peraturan Menteri Pendidikan dan Kebudayaan Republik Indonesia Nomor 23 Tahun 2015 tentang Penumbuhan Budi Pekerti (Permendikbud No. 23/2015), khususnya dalam butir F.VI. mengenai kegiatan gerakan penumbuhan budi pekerti di sekolah, dinyatakan bahwa "sekolah hendaknya memfasilitasi secara optimal agar siswa bisa menemukenali dan mengembangkan potensinya”. Adapun salah satu kegiatan wajib yang terkait dengan hal tersebut adalah "menggunakan 15 menit sebelum hari pembelajaran untuk membaca buku selain buku mata pelajaran (setiap hari)".

\section{Berdasarkan Permendikbud}

tersebut, dapat disimpulkan bahwa sekolah bertanggung jawab mengembangkan budaya baca melalui kegiatan membaca buku non-pelajaran selama 15 menit sebelum memulai jam belajar. Sebelum Permendikbud tersebut terbit, Menteri Pendidikan dan Kebudayaan (Mendikbud) telah mencanangkan "Gerakan 10 Menit Membaca", yang dicetuskan pada 29 Mei 2015 (kemdikbud.go.id). Hal lain yang berkaitan dengan peran sekolah dalam budaya baca adalah bahwa setiap sekolah harus memiliki perpustakaan. Hal ini sesuai amanah Undang-Undang Nomor 43 Tahun 2007 tentang Perpustakaan (Irkham, 2015). Dengan demikian, peran sekolah sangat vital dalam penumbuhan budaya baca sehingga pemerintah, terutama pemerintah daerah, perlu melakukan berbagai upaya untuk mendukung hal tersebut.

Berbicara mengenai peran sekolah dalam menumbuhkan budaya baca berarti kita juga sedang berbicara mengenai peran perpustakaan sekolah. Artinya, perpustakaan sekolah adalah sebagai pusat sumber pengetahuan dan informasi bagi siswa di sekolah-sekolah. Sebagai pusat sumber pengetahuan dan informasi, perpustakaan merupakan sebuah sistem yang berdiri sendiri, yaitu sebuah organisasi yang menghimpun berbagai informasi, baik dalam bentuk buku maupun bukan buku, yang dapat dimanfaatkan oleh pemakai (guru, siswa, dan masyarakat) dalam upaya mengembangkan kemampuan dan kecakapannya (Darmono 2007). Tidak hanya menghimpun informasi, di sana juga ada pengolahan, pengawetan, pelestarian, dan penyajian serta penyebaran informasi (Lasa 2008 dalam Hidayat 2015).

Peran perpustakaan cukup penting dalam proses belajar mengajar di sekolah, 
terutama dalam proses menumbuhkan budaya baca. Dengan membaca, siswa, guru, dan masyarakat akan memperoleh pengetahuan dan informasi. Dalam manifesto IFLA (International Federation of Library Association), yang kemudian diratifikasi oleh UNESCO pada tahun 1999, dinyatakan bahwa perpustakaan sekolah menyediakan informasi dan ideide yang sangat mendasar terhadap berfungsinya dengan sukses suatu masyarakat berbasis informasi dan pengetahuan dewasa ini. Dalam manifesto IFLA juga dinyatakan bahwa perpustakaan sekolah harus membekali siswa dengan keterampilan belajar sepanjang hayat dan mengembangkan imajinasi yang memungkinkan mereka hidup sebagai warna negara yang bertanggung jawab (Siregar 2004). Sementara itu, menurut AECT (Association for Education Communication Technology), perpustakaan adalah salah satu dari sumber belajar. Sumber belajar dalam pengertian ini adalah berupa data, orang, atau wujud tertentu yang dapat digunakan oleh siswa dalam belajar, baik digunakan secara terpisah maupun secara terkombinasi sehingga mempermudah siswa dalam mencapai tujuan belajarnya (Darmono 2007).

Lebih jauh, pentingnya perpustakaan sekolah yang berkualitas tampak pada korelasi yang ditautkan antara kualitas dan/atau kualitas perpustakaan sekolah dengan rendahnya minat baca atau budaya baca. Misalnya, Irkham (2012) mengungkapkan tentang realitas yang berkontribusi terhadap rendahnya minat baca anak, yaitu, pertama, kualitas dan kuantitas perpustakaan sekolah dasar yang tidak memadai. Idealnya, setiap sekolah seharusnya dilengkapi dengan perpustakaan, sesuai amanah UndangUndang Nomor 43 Tahun 2007 tentang Perpustakaan. Kedua, tidak ada integrasi yang nyata, jelas, dan tegas antara mata pelajaran yang diberikan dengan kewajiban siswa untuk membaca. Ketiga, pengalaman pra-membaca dan membaca, atau berkenalan dengan buku, dialami dengan kurang menyenangkan, bahkan buruk. Buku-buku pertama adalah bukubuku tebal yang minim gambar, dengan huruf yang kecil. Pendapat Irkham tersebut memperkuat pemikiraan bahwa perpustakaan sekolah merupakan faktor penting dalam penumbuhan budaya baca.

Sehubungan dengan hal di atas, rendahnya minat baca dapat dikaitkan dengan sejumlah hal yang bersifat struktural, yaitu fasilitas dan kurikulum, yang merupakan produk kebijakan. Terkait dengan isu fasilitas, jumlah dan mutu perpustakaan, baik umum maupun sekolah, tidaklah memadai (Irkham 2012). Kualitas perpustakaan sekolah belum 
memadai sehingga tidak dapat menarik minat siswa untuk berkunjung dan membaca. Selain itu, jumlah perpustakaan umum tidak sebanding dengan jumlah penduduk dan kebutuhan informasi masyarakat dan kualitas jasa dan layanan perpustakaan jauh dari memuaskan (Septiana 2007).

Penjelasan di atas menunjukkan
peran penting sekolah, melalui
perpustakaannya, dalam mewujudkan
budaya baca. Akan tetapi, data menunjukkan bahwa perpustakaanperpustakaan sekolah di Indonesia tidak hanya kekurangan dari segi kualitasnya, tetapi bahkan kekurangan dalam hal kuantitasnya. Hal tersebut berarti bahwa masih banyak sekolah di Indonesia yang tidak memiliki perpustakaan. Sebagai contoh, dari seluruh sekolah dasar (SD) di Indonesia yang berjumlah 148 ribu lebih, hanya 30 persen saja yang memiliki perpustakaan, yaitu 50 ribu SD. Sementara itu, proporsi sekolah menengah pertama(SMP) yang memilikiperpustakaan adalah 36 persen (13 ribu perpustakaan) dan SMA adalah 54 persen (9 ribu perpustakaan) (Irkham 2015).

Kajian pustaka yang telah dilakukan memperlihatkan bahwa perpustakaan sekolah faktor penting dalam mewujudkan budaya baca. Oleh karena itu, diperlukan kebijakan-kebijakan strategis yang dapat mendukung berperannya sekolah dan perpustakaan sekolah dalam penumbuhan budaya baca. Pemerintah daerah di era desentralisasi memiliki wewenang untuk mengatur sekolah dasar hingga menengah, termasuk dalam hal penganggarannya. Sehubungan dengan hal tersebut tulisan ini bermaksud menggambarkan kebijakan pemerintah daerah dalam memperkuat peran sekolah, terutama melalui penyediaan perpustakaan, dalam rangka penumbuhan budaya baca. Pemerintah daerah yang menjadi kasus dalam tulisan ini adalah Pemerintah Kota Surabaya. Kota Surabaya dipilih sebagai kasus karena diketahui telah mencanangkan diri sebagai "kota literasi". Pertanyaan utama yang akan dijawab oleh tulisan ini adalah dengan adanya berbagai wewenang yang telah dilimpahkan oleh pemerintah pusat, kebijakan apakah yang dibuat oleh Pemerintah Kota Surabaya untuk menumbuhkan budaya baca?

\section{METODE PENELITIAN}

Adapun metode yang digunakan dalam penelitian ini adalah metode kualitatif. Pendekatan ini digunakan untuk memahami peran Pemerintah Kota Surabaya dalam penumbuhan budaya baca. Metode pengumpulan data yang digunakan adalah wawancara, pengamatan, dan studi literatur. Data yang dikumpulkan adalah tentang kebijakan-kebijakan Pemerintah 
Kota Surabaya yang terkait dengan upaya menumbuhkan budaya baca di sekolah, khususnya sekolah dasar negeri di wilayahnya.Pengumpulan data dilaksanakan di Kota Surabaya pada pertengahan November 2015. Subyek dalam penelitian ini adalah aparat dari Dinas Pendidikan Kota Surabaya, aparat dari Badan Arsip dan Perpustakaan Kota Surabaya, serta perwakilan siswa, guru, kepala sekolah, dan petugas perpustakaan sekolah. Data tentang kebijakan-kebijakan yang terkait dengan upaya menumbuhkan budaya baca di sekolah didapat dari dokumen-dokumen tentang hal tersebut, di antaranya naskah undang-undang, peraturan pemerintah, peraturan daerah, dan peraturan menteri; dari wawancara dengan para subyek tersebut di atas; serta pengamatan tentang kondisi perpustakaan sekolah.

\section{HASIL DAN PEMBAHASAN}

\section{A. Gambaran Umum Kebijakan \\ Pemerintah Pusat tentang Budaya Baca}

Budaya baca telah menjadi perhatian pemerintah. Hal tersebut tercermin pada beberapa produk hukum yang berkaitan dengan pendidikan, misalnya Undang-Undang Nomor 20 Tahun 2003 tentang Sistem Pendidikan Nasional (UU Sisdiknas), Peraturan Menteri Pendidikan dan Kebudayaan
Republik Indonesia Nomor 23 Tahun 2015 tentang Penumbuhan Budi Pekerti (Permendikbud Budi Pekerti), dan Undang-Undang Nomor 43 Tahun 2007 tentang Perpustakaan (UU Perpustakaan). Dalam UU Sisdiknas Bab III Pasal 4 Ayat (5), dinyatakan bahwa salah satu prinsip penyelenggaraan pendidikan adalah bahwa "Pendidikan diselenggarakan dengan mengembangkan budaya membaca, menulis, dan berhitung bagi segenap warga masyarakat.“ Hal tersebut menunjukkan bahwa pengembangan budaya baca merupakan salah satu hal yang harus diperhatikan dan menjadi orientasi dalam penyelenggaraan pendidikan.

Dalam Permendikbud Budi Pekerti butir F.VI. mengenai kegiatan gerakan penumbuhan budi pekerti di sekolah, dinyatakan bahwa "sekolah hendaknya memfasilitasi secara optimal agar siswa bisa menemukenali dan mengembangkan potensinya”. Adapun salah satu kegiatan wajib yang terkait dengan hal tersebut adalah "menggunakan 15 menit sebelum hari pembelajaran untuk membaca buku selain buku mata pelajaran (setiap hari)". Berdasarkan Permendikbud tersebut, dapat disimpulkan bahwa sekolah bertanggung jawab mengembangkan budaya baca melalui kegiatan membaca buku nonpelajaran selama 15 menit sebelum memulai jam belajar. 
Dalam UU Perpustakaan dalam bagian "Menimbang" butir (c), dinyatakan "bahwa dalam rangka meningkatkan kecerdasan kehidupan bangsa, perlu ditumbuhkan budaya gemar membaca melalui pengembangan dan pendayagunaan perpustakaan sebagai sumber informasi yang berupa karya tulis, karya cetak, dan/atau karya rekam.” Dari poin tersebut tampak bahwa budaya baca menjadi dasar pertimbangan perlunya UU Perpustakaan. Lebih jauh, dalam Pasal 4 undang-undang yang sama dinyatakan bahwa "Perpustakaan bertujuan memberikan layanan kepada pemustaka, meningkatkan kegemaran membaca, serta memperluas wawasan dan pengetahuan untuk mencerdaskan kehidupan bangsa." Hal tersebut berarti bahwa salah satu tujuan perpustakaan adalah meningkatkan kegemaran membaca, satu hal yang merupakan bagian dari penumbuhan baca. Pasal 7 Ayat (1) tentang kewajiban pemerintah terkait perpustakaan menyatakan bahwa pemerintah pusat berkewajiban, di antaranya, untuk "menggalakkan promosi gemar membaca dan memanfaatkan perpustakaan." Pasal tersebut secara eksplisit mengungkapkan adanya kewajiban pemerintah untuk menggalakkan promosi gemarmembaca.

Hal yang senada dinyatakan dalam Pasal 8 tentang kewajiban pemerintah provinsi dan pemerintah kabupaten/kota dalam kaitannya dengan perpustakaan, yaitu bahwa pihak-pihak tersebut wajib "menggalakkan promosi gemar membaca dan memanfaatkan perpustakaan.” Kewajiban melakukan promosi gemar membaca juga dimiliki oleh Perpustakaan Nasional. Hal tersebut tersurat dalam Pasal 21 Ayat (3), yang menyatakan bahwa salah satu tanggung jawab Perpustakaan Nasional adalah "melakukan promosi perpustakaan dan gemar membaca dalam rangka mewujudkan masyarakat pembelajar sepanjang hayat."

$$
\text { Undang-Undang Perpustakan }
$$

memiliki bab tersendiri tentang budaya baca, yaitu Bab XIII tentang Pembudayaan Kegemaran Membaca. Hal tersebut dimulai dengan Pasal 48, yang berisi ayatayat berikut: “(1) pembudayaan kegemaran membaca dilakukan melalui keluarga, satuan pendidikan, dan masyarakat; (2) pembudayaan kegemaran membaca pada keluarga sebagaimana dimaksud pada ayat (1) difasilitasi oleh Pemerintah dan pemerintah daerah melalui buku murah dan berkualitas; pembudayaan kegemaran membaca pada satuan pendidikan sebagaimana dimaksud pada ayat (1) dilakukan dengan mengembangkan dan memanfaatkan perpustakaan sebagai proses pembelajaran; (4) pembudayaan kegemaran membaca pada masyarakat sebagaimana dimaksud pada ayat (1) dilakukan melalui 
penyediaan sarana perpustakaan di tempattempat umum yang mudah dijangkau, murah, dan bermutu. Dalam penjelasan tentang ayat (4) dinyatakan bahwa “pembudayaan kegemaran membaca pada masyarakat, meliputi gerakan buku murah, penerjemahan, penerbitan buku berkualitas, dan penyediaan sarana perpustakaan di tempat-tempat umum (kantor, ruang tunggu, terminal, bandara, rumah sakit, pasar, mall).”

Sebagai tambahan, Pasal 50 menyatakan bahwa "pemerintah dan pemerintah daerah memfasilitasi dan mendorong pembudayaan kegemaran membaca sebagaimana diatur dalam Pasal 48 ayat (2) sampai dengan ayat (4) dengan menyediakan bahan bacaan bermutu, murah, dan terjangkau serta menyediakan sarana dan prasarana perpustakaan yang mudah diakses." Poin penting dari pasal tersebut adalah bahwa pengembangan dan pemanfaatan perpustakaan seharusnya dimaksimalkan untuk menumbuhkan budaya baca. Pasal 49 undang-undang tersebut menyatakan bahwa "pemerintah, pemerintah daerah, dan masyarakat mendorong tumbuhnya taman bacaan masyarakat dan rumah baca untuk menunjang pembudayaan kegemaran membaca." Pasal tersebut menyiratkan bahwa budaya baca dapat ditunjang juga oleh keberadaan taman bacaan masyarakat dan rumah baca.
Sementara itu, Pasal 51 menguraikan tentang gerakan nasional gemar membaca dengan ayat-ayat berikut: (1) pembudayaan kegemaran membaca dilakukan melalui gerakan nasional gemar membaca; (2) gerakan nasional gemar membaca sebagaimana dimaksud pada ayat (1) dilaksanakan oleh Pemerintah dan pemerintah daerah dengan melibatkan seluruh masyarakat; (3) satuan pendidikan membina pembudayaan kegemaran membaca peserta didik dengan memanfaatkan perpustakaan; Perpustakaan wajib mendukung dan memasyarakatkan gerakan nasional gemar membaca melalui penyediaan karya tulis, karya cetak, dan karya rekam; (5) untuk mewujudkan pembudayaan kegemaran membaca sebagaimana dimaksud pada ayat (1), perpustakaan bekerja sama dengan pemangku kepentingan; (6) pemerintah dan pemerintah daerah memberikan penghargaan kepada masyarakat yang berhasil melakukan gerakan pembudayaan gemar membaca; (7) ketentuan mengenai pemberian penghargaan sebagaimana dimaksud pada ayat (6) diatur dengan Peraturan Pemerintah. Lebih lanjut,

Penjelasan undang-undang tersebut menyatakan bahwa "perpustakaan sebagai sistem pengelolaan rekaman gagasan, pemikiran, pengalaman, dan pengetahuan umat manusia, mempunyai fungsi utama 
melestarikan hasil budaya umat manusia tersebut, khususnya yang berbentuk dokumen karya cetak dan karya rekam lainnya, serta menyampaikan gagasan, pemikiran, pengalaman, dan pengetahuan umat manusia itu kepada generasi-generasi selanjutnya. Sasaran dari pelaksanaan fungsi ini adalah terbentuknya masyarakat yang mempunyai budaya membaca dan belajar sepanjang hayat." Tampak bahwa budaya baca merupakan sasaran dari pelaksanaan fungsi perpustakaan. Tinjauan terhadap beberapa peraturan perundangundangan di atas, yaitu Undang-Undang No. 20 Tahun 2003 tentang Sistem Pendidikan Nasional (UU Sisdiknas), Peraturan Menteri Pendidikan dan Kebudayaan Republik Indonesia Nomor 23 Tahun 2015 tentang Penumbuhan Budi Pekerti (Permendikbud Budi Pekerti), dan Undang-Undang Nomor 43 Tahun 2007 tentang Perpustakaan (UU Perpustakaan), menunjukkan bahwa niat untuk menumbuhkan budaya baca telah hadir dalam skema besar tentang pendidikan di Indonesia.

Berdasarkan uraian tersebut, dapat disimpulkan hal-hal sebagai berikut:

1. Menurut UU Sisdiknas:

- pengembangan budaya baca merupakan prinsip penyelenggaraan pendidikan; dan
- perpustakaan sekolah berperan dalam pembudayaan kegemaran membaca.

2. Menurut Permendikbud Budi Pekerti, sekolah memfasilitasi pengembangan budaya baca melalui kegiatan membaca buku non-pelajaran selama 15 menit sebelum memulai jam belajar.

3. Menurut UU Perpustakaan:

- budaya baca menjadi dasar pertimbangan perlunya UU Perpustakaan;

- salah satu tujuan perpustakaan adalah meningkatkan kegemaran membaca;

- promosi gemar membaca menjadi tanggung jawab pemerintah (pusat dan daerah) dan Perpustakaan Nasional;

- budaya baca dapat ditunjang juga oleh keberadaan taman bacaan masyarakat dan rumah baca;

- sekolah membina pembudayaan kegemaran membaca peserta didik dengan memanfaatkan perpustakaan;

- perpustakaan wajib mendukung dan memasyarakatkan gerakan nasional gemar membaca 


\section{JURNAL ILMIAH MIMBAR DEMOKRASI}

melalui penyediaan karya tulis, karya cetak, dan karya rekam;

- untuk mewujudkan

pembudayaan kegemaran

membaca, perpustakaan bekerja sama dengan pemangku kepentingan; dan

- budaya baca merupakan sasaran dari pelaksanaan fungsi perpustakaan.

Poin penting dari uraian di atas adalah bahwa peraturan perundangundangan melihat adanya keterkaitan antara pemerintah (pusat dan daerah), instansi perpustakaan, dan sekolah dalam penumbuhan budaya baca. Pihak-pihak itulah yang berperan penting dalam penumbuhan budaya baca, terutama di sekolah-sekolah.

\section{B. Kebijakan Pemerintah Kota}

\section{Surabaya dalam Penumbuhan}

\section{Budaya Baca}

Pemerintah (pusat dan daerah) telah melakukan upaya-upaya terkait penumbuhan budaya baca, meskipun belum menyeluruh dan maksimal. Pemerintah pusat setidaknya telah mengeluarkan Permendikbud Budi Pekerti. Sementara pemerintah daerah memang bervariasi dalam kebijakannya. Keberadaan beberapa kota dan kabupaten yang telah memiliki kebijakan penumbuhan budaya baca patut diapresiasi. Selain itu, upaya-upaya yang telah mereka lakukan dapat menjadi contoh bagi penerapan kebijakan penumbuhan budaya baca di kabupaten/kota yang lain. Kota Surabaya merupakan contoh dari praktik baik dalam upaya menumbuhkan budaya baca. Kota Padang dengan surat edaran walikotanya juga hal penting yang patut dicatat sebagai bagian dari upaya menumbuhkan budaya baca melalui pengembangan perpustakaan. Secara khusus, sekolah-sekolah telah pula melakukan berbagai hal untuk menumbuhkan budaya baca, dengan segala keterbatasan yang mereka miliki. Jadi, secara umum semua elemen telah melakukan sesuatu, yang perlu diperhatikan adalah kualitas dan kontinuitas dari upaya-upaya tersebut (Solihin et al. 2015).

Salah satu faktor penting dalam upaya penumbuhan budaya baca adalah pelibatan ekosistem pendidikan, di mana pemerintah daerah, dalam hal ini dinas pendidikan dan perpustakaan daerah sebetulnya memiliki peran yang penting. Adanya kebijakan di tingkat pemerintah kota dan kabupaten akan memengaruhi kesiapan sekolah dalam menyelenggarakan program penumbuhan budaya baca. Selain itu, kebijakan di tingkat pemerintah kota dan kabupaten dapat mempercepat dan memperluas gerakan budaya baca, tidak 
hanya pada satu atau dua sekolah saja, melainkan ke semua sekolah, baik swasta maupun negeri, di semua jenjang pendidikan dasar hingga menengah. Pada bagian ini akan dideskripsikan peran dan kebijakan Pemerintah Kota Surabaya dalam penumbuhan budaya baca; bagaimana Kota Surabaya mencanangkan dirinya sebagai Kota Literasi, serta kebijakan-kebijakan apa saja yang telah ditempuh dan bagaimana dampaknya. Kasus Kota Surabaya dapat menjadi contoh bagaimana gerakan literasi yang diinisiasi oleh pemerintah daerah dapat dilakukan dengan lebih agresif dan dampaknya nyata bagi penumbuhan budaya baca bagi masyarakatnya.

Kota Surabaya mencanangkan diri sebagai Kota Literasi pada tanggal 2 Mei 2014. Gerakan ini dilatarbelakangi kenyataan bahwa masyarakat di Kota Surabaya memiliki minat baca rendah. Dengan pencanangan Kota Literasi yang tentu saja diikuti dengan berbagai upaya oleh instansi terkait, terjadi peningkatan dalam berbagai indikator yang terkait dengan literasi di kota tersebut. Pada tahun 2010, hasil survei terhadap 20.000 responden, menunjukkan bahwa minat baca masyarakat Kota Surabaya hanya sekitar $26 \%$, yang berarti bahwa minat baca di kota itu masih tergolong rendah. Melalui berbagai upaya yang ditempuh oleh kota ini, yaitu khususnya oleh Badan
Arsip dan Perpustakaan (Barpus) Kota Surabaya dan Dinas Pendidikan (Disdik) Kota Surabaya, minat baca masyarakat Kota Surabaya meningkat. Survei yang dilakukan oleh Pemerintah Kota Surabaya di tahun 2015 menunjukkan minat baca masyarakat Kota Surabaya meningkat menjadi 59,6\%, dari sebelumnya $38 \%$ pada tahun 2011 dan $26 \%$ pada tahun 2010. Selain itu, indikator-indikator lain yang terkait dengan literasi juga mengalami peningkatan, misalnya data kunjungan ke perpustakaan. Data kunjungan ke perpustakaan umum, taman bacaan, dan perpustakaan sekolah di tahun 2014 tercatat mencapai 17.735 .360 kunjungan. Dari jumlah tersebut, mayoritas kunjungan dilakukan oleh pelajar, yaitu sebesar 17.492.562 kunjungan. Adapun data tahun 2015, hingga bulan September 2015, kunjungan ke perpustakaan telah mencapai 12.742.657 kunjungan.

Upaya yang dilakukan oleh Pemerintah Kota Surabaya untuk meningkatkan minat baca masyarakatnya sebetulnya telah dimulai sejak tahun 2007. Pada waktu itu, jumlah kunjungan ke perpustakaan kota sangat sedikit, sehingga timbul keprihatinan dari pemerintah. Walikota Surabaya kemudian mengeluarkan kebijakan untuk memperbanyak taman bacaan, yang tujuan utamanya adalah untuk mempermudah 
akses bacaan bagi masyarakat. Para petugas taman bacaan ini direkrut dari warga sekitar (Pakistyaningsih 2014). Di tahun 2009, Badan Arsip dan Perpustakaan Kota Surabaya membuka 14 taman bacaan. Program lanjutan tersebut lebih serius dan terencana, yaitu dengan penggunaan tenaga pengelola yang direkrut khusus, tidak lagi menggunakan tenaga dari masyarakat sekitar. Hal tersebut dilatarbelakangi hasil evaluasi terhadap pengelolaan taman bacaan, yang menunjukkan bahwa sumber daya manusiaa pengelola perpustakaan (taman bacaan) merupakan salah satu kunci untuk meningkatkan minat baca masyarakat (Pakistyaningsih 2014).

Meskipun sepintas tampak menggembirakan, berbagai upaya untuk mengembangkan literasi di Kota Surabaya melalui pembangunan dan pengembangan taman bacaan dianggap belum begitu berhasil secara maksimal. Hal itu karena sasaran utama pelayanan perpustakaan publik di Kota Surabaya adalah para pelajar. Dalam rangka menyikapi hal tersebut, khususnya dalam rangka meningkatkan literasi di kalangan pelajar, Pemerintah Kota Surabaya melalui Badan Arsip danPerpustakaan Kota Surabaya lantas merumuskan program budaya baca dengan singkatan SPOP, yang kepanjangannya adalah subyek, program, obyek, dan prasarana. Penjelasan dari program SPOP adalah: pertama, subyek berarti pertugas perpustakaan yang terlatih dan memiliki semangat kerja tinggi. Kedua, program berarti program kerja. Ketiga, obyek berarti sasaran, yaitu pelajar, terutama pelajar sekolah dasar. Keempat, prasarana yang berupa perpustakaan dan koleksi yang memadai (Pakistyaningsih 2014).

Dalam rangka mendukung program SPOP, instansi terkait kemudian melakukan upaya-upaya yang dapat mendukung keberhasilan program tersebut. Badan Arsip dan Perpustakaan Kota Surabaya kemudian bekerja sama dengan Dinas Pendidikan Kota Surabaya untuk merevitalisasi 463 perpustakaan sekolah dasar negeri yang ada di kota itu. Revitalisasi mencakup segi bangunan fisik, sarana dan prasarana, serta programprogram yang diselenggarakan oleh perpustakaan sekolah. Hingga tahun 2015, tercatat sebanyak 1.613 perpustakaan sekolah dasar negeri di Kota Surabaya sudah direvitalisasi. Upaya ini merupakan langkah awal untuk membentuk masyarakat pembaca, yaitu para pelajar, sehingga dengan meningkatnya minat baca, kunjungan dan aktivitas di perpustakaan sekolah dan perpustakaan publik dapat meningkat. Kerja sama antara Badan Perpustakaan dan Arsip dan Dinas Pendidikan Kota Surabaya menunjukkan bahwa kerja sama yang erat dapat 
mempercepat dan meluaskan dampak dari upaya penumbuhan budaya baca.

Selain hal-hal tersebut di atas, Pemerintah Kota Surabaya juga melaksanakan beberapa strategi yang terkait dengan pengembangan literasi, khususnya penumbuhan budaya baca. strategi-strategi tersebut adalah, pertama, penerbitan regulasi. Untuk mendukung upaya yang dilakukan oleh Badan Perpustakaan dan Arsip dan Dinas Pendidikan Kota Surabaya, Pemerintah Kota Surabaya mengeluarkan dua peraturan, yaitu Peraturan Daerah (Perda) Nomor 5 Tahun 2009 tentang Penyelenggaraan dan Pengelolaan Perpustakaan dan Peraturan Walikota Surabaya Nomor 11 Tahun 2010 tentang Pelaksanaan Penyelenggaraan dan Pengelolaan Perpustakaan. Perda Nomor 5 Tahun 2009 tentang Penyelenggaraan dan Pengelolaan Perpustakaan merupakan peraturan pelaksana di tingkat daerah, sebagai kelanjutan dari UU Nomor 43 Tahun 2007 tentang Persputakaan, dan Peraturan Pemerintah Nomor 24 Tahun2014 tentang Pelaksanaan UU Nomor 43tentang Pengelolaan Perpustakaan. Sebagai kelanjutan dari Perda Nomor 5 Tahun 2009 tersebut, dikeluarkan pula Peraturan Walikota Surabaya Nomor 11 Tahun 2010 tentang Pelaksanaan Penyelenggaraan dan Pengelolaan Perpustakaan.
Kedua, sinergi antara Badan Arsip dan Perpustakaandengan Dinas Pendidikan Kota Surabaya. Salah satu modal kunci dari keberhasilan Kota Surabaya dalam menumbuhkan budaya baca adalah sinergi antara Badan Arsip dan Perpustakaandengan Dinas Pendidikannya. Sinergi ini diwujudkan melalui naskah kerja sama antara kedua intsansi tersebut dalam rangka pembinaan perpustakaan sekolah. Secara umum, pembagian kerja antara Badan Arsip dan Perpustakaan dengan Dinas Pendidikan Kota Surabaya terbagi menjadi dua, yaitu bahwa sarana dan prasarana perpustakaan merupakan kewenangan dari Dinas Pendidikan, sementara sumber daya manusia pengelola perpustakaan merupakan tanggung jawab Badan Arsip dan Perpustakaan Kota Surabaya.

Selain sarana dan prasaranaa perpustakaan sekolah, ada pula perpustakaan keliling milik Badan Arsip dan Perpustakaan Kota Surabaya yang juga melayani kebutuhan bahan bacaan di sekolah-sekolah dan tempat-tempat umum. Badan Arsip dan Perpustakaan juga mendukung penambahan koleksi perpustakaan sekolah melalui bantuan buku dan program buku bergilir. Sarana dan prasarana perpustakaan sekolah didorong agar mengikuti standar nasional perpustakaan, sehingga kondisi bangunan, fasilitas, dan jumlah koleksinya memadai. 


\section{JURNAL ILMIAH MIMBAR DEMOKRASI}

64

VOLUME 17, NOMOR 1, OKTOBER 2017

Selain itu, setiap kelas juga didorong agar memiliki sudut baca, tujuannya adalah untuk mendekatkan bahan bacaan kepada siswa. Sudut baca juga berguna untuk mensukseskan program 15 menit membaca sebelum pelajaran dimulai.

Dinas Pendidikan Kota Surabaya juga mengeluarkan surat edaran tentang kurikulum wajib baca, yang isinya berupa himbauan agar setiap sekolah mewajibkan siswanya untuk berkunjung ke perpustakaan. Kunjungan wajib ke perpustakaan ini minimal diselenggarakan seminggu sekali dan digilir bagi setiap kelas dan jenjang. Untuk memaksimalkan program ini, guru kelas dan pengelola perpustakaan menyusun program bersama.

Ketiga, pengembangan sumber daya manusia pengelola perpustakaan. Tenaga pengelola perpustakaan diatur dalam Peraturan Daerah (Perda) Nomor 5 Tahun 2009. Dalam praktiknya, Badan Arsip dan Perpustakaan Kota Surabaya merekrut 555 orang tenaga pengelola perpustakaan dengan gaji setara upah minimum regional (UMR) untuk mengelola perpustakaan di sekolah dasar dan taman bacaan di permukiman masyarakat. Gaji tenaga perpustakaan dibayar melalui anggaran Badan Arsip dan Perpustakaan Kota Surabaya.

Para pengelola perpustakaan yang direkrut secara khusus itu, tidak hanya direkrut dan dipekerjakan begitu saja, mereka juga mendapatkan berbagai pelatihan. Sejak tahun 2011, para pengelola perpustakaan yang direkrut khusus itu mendapatkan berbagai pelatihan, baik dari segi pengelolaan perpustakaan, perancangan programprogram yang terkait literasi, hingga kiat mencari bantuan untuk tambahan koleksi buku. Satu minggu sekali, semua pengelola perpustakaan berkumpul untuk berdiskusi mengenai penyelenggaraan program mereka di tiap-tiap lokasi. Selain bertugas di perpustakaan sekolah, tenaga pustakawan ini juga merangkap sebagai pendamping taman bacaan di permukiman warga. Untuk meningkatkan minat kunjungan ke taman bacaan, pengelola perpustakaan menyusun program-program yang dianggap menarik, termasuk menyelenggarakan bimbingan belajar gratis kepada anak-anak di sekitar taman bacaan.

Dalam melaksanakan tugasnya, para pengelola perpustakaan dipantau langsung oleh masing-masing koordinator wilayah, di mana seluruh Kota Surabaya terbagi ke dalam 6 koordinator wilayah. Untuk memantau kinerja pengelola perpustakaan, Badan Arsip dan Perpustakaan Kota Surabaya memiliki beberapa cara, antara lain melalui grup aplikasi percakapan dalam jaringan (online chatting application) LINE untuk berkomunikasi secara langsung antara 
pengelola perpustakaan dan koordinator wilayah, serta dengan membuka layanan pesan singkat yang dibuka untuk umum, sehingga siswa atau warga di sekitar perpustakaan sekolah dan taman bacaan dapat menyampaikan aspirasi dan/atau keluhannya. Aspirasi dan/atau keluhankeluhan tersebut akan direspon langsung oleh masing-masing koordinator wilayah.

Dengan adanya petugas pengelola perpustakaan sekolah yang terlatih ini, pihak sekolah sangat terbantu karena mereka hanya perlu menyediakan sarana berupa perpustakaan dan koleksi bacaan yang memadai. Hal itupun dapat diakatakan sebagai urusan yang kecil karena sarana perpustakaan sekolah merupakan kewenangan dari Dinas Pendidikan Kota Surabaya. Hal tersebut berarti bahwa sekolah sangat dilayani oleh instansi terkait dalam urusannya menumbuhkan budaya baca.

Keempat, pelaksanaan program penumbuhan budaya baca. Selain sinergi antara Badan Arsip dan Perpustakaan dengan Dinas Pendidikan Kota Surabaya, hal lain yang perlu dicatat adalah berbagai program literasi yang diadakan oleh Pemerintah Kota Surabaya. Berbagai kegiatan literasi ini meliputi kampanye gemar membaca yang diselenggarakan di tempat-tempat umum, berbagai perlombaan, dan program Tantangan Membaca.
Untuk memacu minat siswa menulis cerita, Dinas Pendidikan Kota Surabaya telah menyelenggarakan lomba menulis cerita bagi siswa SD, SMP, dan SMA. Setiap siswa dianjurkan untuk menulis cerita. Masing-masing sekolah kemudian memilih cerita terbaik yang akan dilombakan di tingkat kecamatan. Para pemenang di tingkat kecamatan lantas dilombakan lagi di tingkat Kota Surabaya. Naskah cerita terbaik kemudian diterbitkan dan didistribusikan ke seluruh perpustakaan sekolah dan taman bacaan di Kota Surabaya.

Sementara itu, pada tahun 2015, Dinas Pendidikan Kota Surabaya menyelenggarakan program Tantangan Membaca Satu Juta Buku. Untuk menyukseskan program ini, siswa SD ditantang untuk membaca 20 buku, siswa SMP sebanyak 15 buku, dan siswa SMA sebanyak 10 buku. Dari total siswa yang lebih dari 6 juta orang, Dinas Pendidikan Kota Surabaya optimis bahwa target tersebut dapat tercapai. Dalam pelaksanaannya, para siswa diminta untuk mencatat dan menuliskan ringkasan dari isi buku yang dibaca. Catatan siswa tersebut kemudian direkap oleh masing-masing guru kelas. Dari rekap catatan siswa ini dapat diketahui berapa buku yang telah dibaca selama satu tahun. Dinas Pendidikan Kota Surabaya juga berencana memberikan sertifikat bagi siswa yang 
mampu menyelesaikan target jumlah bacaan tersebut. Hal tersebut juga tentunya dapat menjadi motivasi bagi setiap siswa untuk dapat membaca sebanyak mungkin buku, atau setidaknya sesuai jumlah yang ditargetkan.

Kelima, pelibatan ekosistem pendidikan. Kunci sukses lain dari program literasi, khususnya penumbuhan budaya baca, di Kota Surabaya adalah pelibatan ekosistem pendidikan. Selain kerja sama antara Badan Arsip dan Perpustakaandengan Dinas Pendidikan Kota Surabaya, Pemerintah Kota Surabaya juga melibatkan dua pihak lain, yaitu perusahaan-perusahaan swasta melalui program tanggung jawab sosial perusahaan atau corporate social responsibility (CSR) serta melibatkan berbagai perguruan tinggi yang ada di Kota Surabaya melalui program tanggung jawab sosial kampus atau campus social responsibility (CSR). Dalam pelaksanaannya, perusahaanperusahaan diminta untuk mendukung dengan cara mendanai berbagai program pengembangan literasi serta memberikan bantuan donasi buku bagi perpustakaan umum dan perpustakaan sekolah. Sementara perguruan tinggi diminta menerjunkan mahasiswa untuk turut mendampingi program literasi di masyarakat.

Uraian di atas menunjukkan bahwa Pemerintah Kota Surabaya telah melakukan berbagai strategi dalam rangka penumbuhan budaya baca, dengan payung besar Surabaya sebagai Kota Literasi. Strategi-strategi tersebut meliputi aspek regulasi, pendanaan, penyelenggaran kegiatan, dan kerja sama. Aspek regulasi, yaitu penerbitan Peraturan Daerah (Perda) Nomor 5 Tahun 2009 tentang Penyelenggaraan dan Pengelolaan Perpustakaan dan Peraturan Walikota Surabaya Nomor 11 Tahun 2010 tentang Pelaksanaan Penyelenggaraan dan Pengelolaan Perpustakaan menjadi payung hukum bagi implementasi keseluruhan program untuk mendukung penumbuhan budaya baca. Kedua regulasi tersebutlah yang memungkinkan hadirnya sinergi antara pihak-pihak terkait beserta pembagian tugasnya, teralokasinya dana yang mendukung program-program serta kegiatan-kegiatan yang disusun, serta terjalinnya kerja sama dengan berbagai pihak.

Di luar itu semua, keleluasaan Pemerintah Kota Surabaya dalam mendesain dan mengimplementasikan berbagai program dalam rangka penumbuhan budaya baca dimungkinkan karena adanya desentralisasi. Desentralisasi memberikan ruang gerak lebih besar kepada pemerintah daerah, dalam hal ini Pemerintah Kota Surabaya, untuk melakukan berbagai intervensi terhadap sekolah-sekolah dan 
perpustakaan-perpustakaan, menerbitkan regulasi, mengalokasikan anggaran, dan menjalin kerja sama dengan berbagai pihak.

\section{KESIMPULAN}

Literasi, khususnya budaya baca, telah menjadi perhatian pemerintah pusat dan daerah. Berbagai peraturan perundangundangan yang dikeluarkan oleh pemerintah pusat menjadi gambaran tentang bagaimana perhatian terhadap budaya baca itu diwujudkan. Pemerintah daerah pun tidak kalah berperan dalam penumbuhan budaya baca ini, meskipun belum semuanya maksimal. Mengingat kebijakan merupakan elemen penting dalam upaya-upaya penumbuhan baca, maka pemerintah daerah sangat dinantikan perannya. Desentralisasi telah memberi ruang kepada pemerintah daerah untuk membuat kebijakan yang sesuai dengan kebutuhannya, terlepas dari ketiadaan, kekurangan, atau keterbatasan instrumen kebijakan dari pusat. Pemerintah Kota Surabaya telah mampu untuk mengambil peran dalam menumbuhkan budaya baca dengan kebijakan-kebijakan lokalnya, sekaligus menutup lubang kosong kebijakan pemerintah pusat dalam pengembangan literasi.

Dengan adanya wewenang yang terwujud karena bergulirnya desentralisasi, Pemerintah Kota Surabaya dapat merancang dan mengimplementasikan berbagai kebijakan dalam rangka menumbuhkan budaya baca. Kebijakankebijakan tersebut pada intinya berkaitan dengan penerbitan regulasi yang kemudian menjadi payung hukum bagi pelaksanaan berbagai program dan kegiatan, alokasi anggaran, sinergi antara lembaga pemerintah terkait, dan kerja sama dengan berbagai pihak. Temuan penelitian menunjukkan bahwa di tengah berbagai keterbatasan instrumen kebijakan yang terkait dengan literasi, khususnya penumbuhan budaya baca, Pemerintah Kota Surabaya mencanangkan diri sebagai "kota literasi", yang diikuti berbagai kebijakan yang mendukung pengembangan literasi. Kebijakankebijakan tersebut adalah penerbitan regulasi yang mendukung penumbuhan budaya baca, sinergi antara instansi pemerintahan terkait, pengembangan sumber daya manusia pengelola perpustakaan, penyelenggaraan kegiatankegiatan yang mendukung penumbuhan budaya baca, dan pelibatan ekosistem pendidikan. Hasil dari kebijakan-kebijakan tersebut adalah terjadinya peningkatan minat baca masyarakat yang ditopang oleh program-program literasiyang berkelanjutan.

Kota Surabaya dapat menjadi contoh kota yang memiliki praktik baik dalam upaya penumbuhan budaya baca. 
Oleh karena itu, pemerintah pusat perlu mengidentifikasi dan merumuskan semacam model kebijakan pemerintah daerah yang sekiranya dapat diadaptasi oleh pemerintah daerah yang lain. Dari cara pandang lain, pemerinta daerah yang lain yang ingin menjalankan program serupa dapat secara proaktif mempelajari strategi-strategi yang dilakukan Pemerintah Kota Surabaya dan mencoba mengadaptasikannya sesuai dengan konteks dan kebutuhannya masing-masing.

\section{DAFTAR PUSTAKA}

Darmono. 2007. "Pengembangan perpustakaan sekolah sebagai sumber belajar", dalam Jurnal Perpustakaan Sekolah 1 (1), diunduh dari http://library.um.ac.id/images/gbjps /art01dar.pdf pada tanggal 25 Oktober 2015.

Hastari, G. R. 2015. Kesuksesantaman bacaan masyarakat Rumah Dunia dalam pemberdayaan masyarakat melalui program literasi informasi. Skripsi S-1 pada Program Studi Ilmu Perpustakaan, Fakultas Adab dan Humaniora, Universitas Islam Negeri Syarif Hidayatullah, Jakarta. Tidak diterbitkan.
Hidayat, R. A. 2015. Peran warga sekolah dalammemanfaatkan perpustakaan untuk meningkatkan minat baca siswa di SD Negeri Gembongan. Skripsi S-1 Program Studi Pendidikan Guru Sekolah Dasar Jurusan Pendidikan Pra-Sekolah dan Sekolah Dasar, Universitas Negeri Yogyakarta, diunduh dari http://eprints.uny.ac.id/16337/1/Ra khmat\%20Arif\%20Hidayat.pdf pada tanggal 25 Okrober 2015.

International Federation of Library Associations and Institutions (IFLA). 2007. Developing cultures of literacy: an international research project preliminary report.

Irkham, A. M. 2015. "Minat baca tak bisa menunggu" dalam http://www.tempo.co/read/kolom/2 015/08/19/2261/minat-baca-takbisa-menunggu, diakses pada tanggal 23 Oktober 2015.

Irkham, A. M. 2012. "Minat baca anak Indonesia", dalam Gol A Gong dan Agus M. Irkham, Gempa literasi: Dari kampung untuk Nusantara.Jakarta: Kepustakaan Populer Gramedia. 
Jamaluddin, 2005. Problematik pembelajaran bahasa dan sastra. Yogyakarta:Adicita Karya Nusa.

Kusumah, S. D., et al. 2013. Apresiasi sastra di kalangan pelajar SMA (Kasus Kota Tanjungpinang dan Makassar). Laporan penelitian pada Pusat Penelitian dan Pengembangan Kebudyaan, Kementerian Pendidikan dan Kebudayaan, Jakarta. Tidak diterbitkan.

Laksmi. 2007. "The Effectiveness of Reading Habit Promotion in Public Libraries of DKI Jakarta Province", dalam Abrizah Abdullah, et al. (Eds.), ICOLIS 2007. Kuala Lumpur: LISU, FCSIT, 2007: pp 165-172.

Mullis, I.V.S. et al. 2011. Progress in International Reading Literacy Study (PIRLS) 2011: International result in reading. Boston: TIMSS\&PIRLS.

Organisation for Economic Co-operation and Development (OECD). 2010. PISA 2009 result: Executive summary, diunduh dari www.oecd.org/publishing/corrigen da pada tanggal 23 Oktober 2015.

Peraturan Daerah Kota Surabaya Nomor 5 Tahun $2009 \quad$ tentang Penyelenggaraan dan Pengelolaan Perpustakaan (Perda tentang Perpustakaan), diunduh dari http://www.jdih.setjen.kemendagri. go.id/files/KOTA_SURABAYA_5 _2009.pdf pada tanggal 1 Desember 2015.

Peraturan Menteri Pendidikan dan Kebudayaan Republik Indonesia Nomor 23 Tahun 2015 tentang Penumbuhan Budi Pekerti, diunduh dari

http:/hukor.kemdikbud.go.id/asbod oku/media/peruu/Permendikbud_T ahun2015_Nomer023.pdf pada tanggal 23 Oktober 2015.

Peraturan Walikota Surabaya Nomor 11 Tahun 2010 tentang Pelaksanaan Perda Nomor 5 Tahun 2009 tentang Penyelenggaraan dan Pengelolaan Perpustakaan, diunduh dari http://jdih.surabaya.go.id/pdfdoc/pe rwali_451.pdf pada tanggal 1 Desember 2015. 
Pakistyaningsih, A. et al. 2014. Menuju wujud Surabaya sebagai kota literasi. Surabaya: Pelita Hati

Programme for International Student Assessment (PISA). 2012. PISA results 2012, diunduh dari http://www.theguardian.com/news/ datablog/2013/dec/03/pisa-resultscountry-best-reading-maths-science pada tanggal 27 Oktober 2015.

Rosser, A. \& Sulistiyanto, P. 2013. "The politics of universal free basic education in decentralized Indonesia: Insights from Yogyakarta", dalam Pacific Affairs 86(3): 539-560.

Septiana, R. I. 2007. Perkembangan perpustakaan berbasis komunitas: Studi kasus pada Rumah Cahaya, Melati Taman Baca dan Kedai Baca Sanggar Barudak. Skripsi S-1 pada Program Studi Ilmu Perpustakaan dan Informasi Universitas Indonesia, Depok. Tidak diterbitkan.

Siregar, A. R. 2004. "Penguatan perpustakaan sekolah", diunduh dari http://repository.usu.ac.id/bitstream $/ 123456789 / 1735 / 1 /$ Penguatan $\% 20$
Perp\%20Sekolah.pdf pada tanggal 25 Oktober 2015.

Siregar, A. R. 2008. "Upaya meningkatkan minat baca di sekolah", diunduh dari http://repository.usu.ac.id/bitstream /123456789/1750/1/08E00537.pdf pada tanggal 25 Oktober 2015.

Solihin, L. 2014. "Jangan sampai rabun membaca dan pincang menulis: Catatan pasca-kegiatan 3 Hari Mengapresiasi Sastra” dalam Bambang Widiatmoko, Musoffa Ikhsan, dan Lukman Solihin (eds.), Yang muda yang bersastra: Kumpulan cerpen dan puisi 3 hari mengapresiasi sastra 2014. Jakarta: Puslitbang Kebudayaan.

Solihin, L. et al. 2015. Peran Sekolah dalam Penumbuhan Budaya Baca. Laporan penelitian pada Pusat Penelitian Kebijakan Pendidikan dan Kebudyaan, Kementerian Pendidikan dan Kebudayaan, tidak diterbitkan.

Toi, A. 2010. “An empirical study of the effects of decentralization in Indonesian junior secondary education", in Educational 
Research for Policy \& Practice 9: 107-125.

Undang-Undang Republik Indonesia Nomor 20 Tahun 2003 Tentang Sistem Pendidikan Nasional, diunduh dari http://sdm.data.kemdikbud.go.id/S NP/dokumen/undang-undang-no20-tentang-sisdiknas.pdf pada tanggal 23 Oktober 2015.

Undang-Undang Nomor 43 Tahun 2007 tentang Perpustakaan (UU Perpustakaan), diunduh dari http://perpusnas.go.id/iFileDownlo ad.aspx ?ID=Attachment\%5CProdu kHukum\%5CUU\%2043\%202007 \%20PERPUSTAKAAN.pdf pada tanggal 23 Oktober 2015.

United Nations Educational, Scientific and Cultural Organisation (UNESCO). 2012. Adult and youth literacy, 1990 - 2015 analysis of data for 41 selected countries. Canada: UNESCO Institute for Statistics.

Wahyudin, U. 2015. "The quality of a 'local values based' fuctional literacy program: Itscontribution to the improvement of the learner's basic competencies", dalam International Education Studies 8 (2): 121-127.

\section{Sumber Internet:}

http://www.kemdikbud.go.id/main/blog/20 15/05/mendikbud-canangkangerakan-10-menit-membaca-ceritauntuk-anak-4246-4246-4246, diakses pada tanggal 23 Oktober 2015.

http://www.kemdikbud.go.id/main/gallerie s/mendikbud-canangkan-gerakan10-menit-membaca-cerita-untukanak-4250-4250, diakses pada tanggal 23 Oktober 2015. 